\title{
Measurement push and pull forces on automatic liquid dispensers
}

\author{
Agustami Sitorus' ${ }^{1}$ Eko K. Pramono ${ }^{2}$, Yusnan H. Siregar ${ }^{3}$, Ari Rahayuningtyas ${ }^{4}$, \\ Novita D. Susanti ${ }^{5}$, Irwin S. Cebro ${ }^{6}$, Ramayanty Bulan ${ }^{7}$ \\ $1,2,3,4,5$ Research Center for Appropriate Technology, Indonesian Institute of Sciences, Subang, Indonesia \\ ${ }^{6}$ Department of Mechanical Engineering, Lhokseumawe State Polytechnic, Lhokseumawe, Indonesia \\ ${ }^{7}$ Department of Agricultural Engineering, Faculty of Agriculture, Syiah Kuala University, Indonesia
}

\section{Article Info}

Article history:

Received Jan 29, 2021

Revised May 3, 2021

Accepted May 17, 2021

\section{Keywords:}

Appropriate technology

Automatic liquid dispensers

Hand sanitizer

Liquid soap

Push and pull forces

\begin{abstract}
Since the COVID-19 pandemic, automated liquid dispensers have been increasingly developed to assist transmission prevention. However, data availability of automatic liquid dispenser mechanism's technical characteristics is not yet widely available. This causes frequent over or under design in its development. Therefore, we specifically measure push and pull forces engineering characteristics generated by the automatic liquid dispenser mechanism. A wire mechanism-based automatic liquid dispenser apparatus was used to experiment. A load-cell sensor was used to detect the force that occurs from a servo motor controlled by a microcontroller. The force data (push and pull) will be sent directly to the database server cloud with a recording frequency of every second. Three types of fluid treatment levels are used i.e. water, liquid soap, and hand sanitizer gel. Three types of fluid volume treatment levels used were $50 \mathrm{ml}, 150 \mathrm{ml}$, and $250 \mathrm{ml}$. Each treatment level combination is carried out at the servo motors rotation steps $180^{\circ}, 150^{\circ}, 120^{\circ}, 90^{\circ}, 60^{\circ}$, and $30^{\circ}$. The results show that no significant differences were found in maximal forces required to release the water, liquid soap, and hand-sanitizer gel. It is also known that the volume of the fluid has a very significant effect on the amount of push and pull forces generated.
\end{abstract}

This is an open access article under the CC BY-SA license.

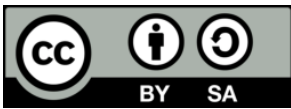

\section{Corresponding Author:}

Ramayanty Bulan

Department of Agricultural Engineering

Faculty of Agriculture

Syiah Kuala University

Banda Aceh, Indonesia

Email: ramayantybulan@gmail.com,rama_bulan@unsyiah.ac.id

\section{INTRODUCTION}

The outbreak of the COVID-19 disease at the end of 2019 created a cleaner lifestyle globally, including in Indonesia. Recommendations for using masks and frequent washing of hands using soap or hand sanitizers have been campaigned massively to stop the spread of the outbreak. The equipment and technology to support these activities finally received special attention, especially the supporting equipment for washing hands. Some of these innovations can be found in various electronic and printed mass media. Unfortunately, these innovations have not been legally registered as intellectual property.

In this context, during the last couple of months, one of the innovations of concern was the development of automatic liquid dispensers for hand sanitizer and liquid soap. Several innovations are quoted on the page www.timesindonesia.co.id [1]. The innovator developed a tool to automatically provide hand 
sanitizer fluid based on a microcontroller using the HCSR-04 sensor. A servo motor is used to press the head of the liquid bottle to release the hand sanitizer liquid. The power source used by this device is from a portable power bank.

Another relevant innovation, such as on the page https:/unkhair.ac.id [2], is where innovators develop a tool to provide liquid soap and clean water for washing hands automatically. This innovation uses a microcontroller technology with an infrared sensor to detect objects given liquid soap and clean water. A mini water pump is used to pump liquid soap, and an automatic tap is used to distribute clean water. Unfortunately, it is necessary to be documented to become scientific documentation in scientific papers or intellectual property.

Some scientific relevant studies related to the automatic liquid dispensers mechanism to deal with COVID-19 were conducted by Karn et al. [3], and Edgar-Tanzil [4]. Karn et al. [3] conducted a study related to the design and development of an automated monitored hand hygiene system to curb infection spread in institutional settings. The authors' research problem is how to design a low-cost, touch-free, automated, and monitorable handwashing unit system.

The mechanism developed Karn et al. [3] is to use a rack and pinion mechanism as shown in Figure 1. However, this study's results are still in the form of a design planning report and have not been manufactured so that they can be used. Another relevant study from Edgar-Tanzil [4] is also still in the form of a brief design of a solution to address the spread of COVID-19 in North America.

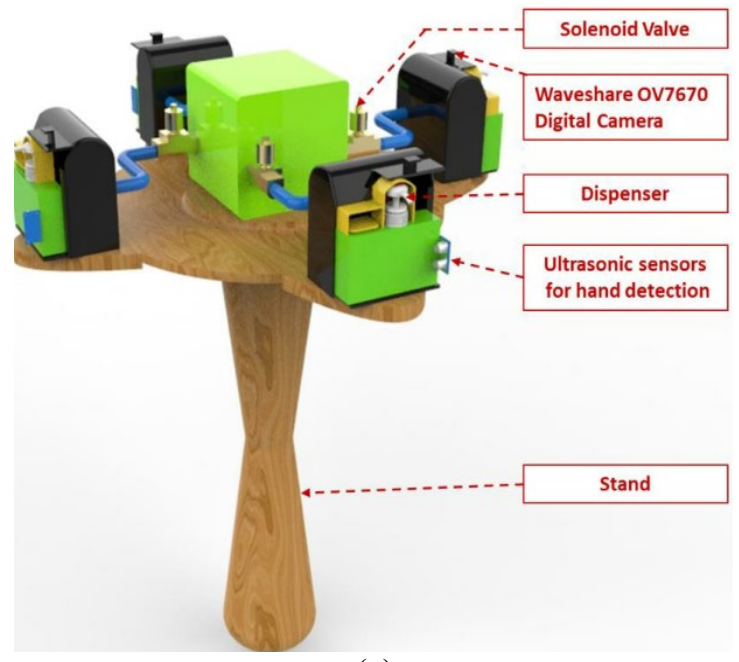

(a)

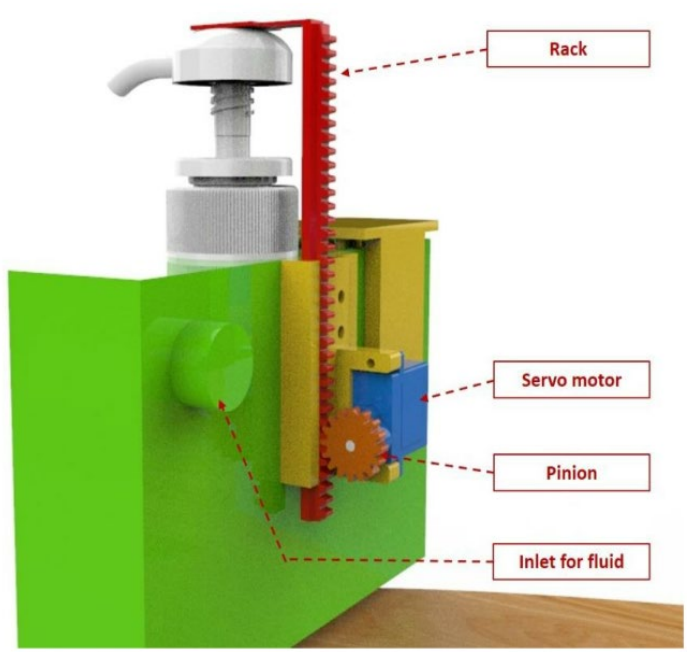

(b)

Figure 1. Automated and monitored hand hygiene system developed by Karn et al. [3]; (a) full design, (b) backside isometric view

Surprisingly, the basic studies related to providing engineering data to design automatic liquid dispensers for hand sanitizer liquid, liquid soap and alcohol-based hand rub dispensers have not been reviewed in depth. Actually, there are a variety of commercially produced automatic dispensers with various operating mechanisms. The gravitational dispensing system, as defined by Bansaghi et al. [5] and Lehotsky et al. [6], is used by the majority of newly developed hand-rub dispensers. However, no research has been done on the force needed by an automatic dispenser for hand sanitizer liquid and liquid soap with a normal pumping mechanism. This research is necessary to prevent underdesigning or overdesigning the equipment that will be manufactured. According to Han [7] and Sitorus et al. [8], under design will cause problems, including economic life, and equipment performance is not expected. According to Zhu and Deshmukh [9] and Babbitt et al. [10], over design will cause problems, including wasteful materials, so that the resulting equipment's production costs will be higher.

In that respect, investigations related to the force needed to predict the power applied to automatic liquid dispensers have not been investigated in depth. This becomes very important to predict power requirements, especially if you use the battery as a power source for the pumping fluid. Therefore, In the present work, we present an in-depth measurement related to the technical characteristics of the push and pull forces of the automatic liquid dispenser (regular pumping) mechanism for hand sanitizer fluids, liquid soap, and water (only one type of dispenser and dispenser bottle). 


\section{RESEARCH METHOD}

An experimental apparatus is designed to acquire push and pull forces data from a bottle of automatic liquid dispensers. The schematic diagram of the apparatus is presented in Figure 2. The automatic liquid dispenser bottle used in this study was obtained from the local market (Subang, West Java, Indonesia), which has dimensions of length, width, and height of $85 \mathrm{~mm}, 50 \mathrm{~mm}$, and $175 \mathrm{~mm}$, respectively. The maximum volume of the bottle is $250 \mathrm{ml}$. A load cell sensor with a $5 \mathrm{~kg}$ capacity HX711 module [11]-[13] was used to measure push and pull forces. Servo motor (Tower Pro MG995 type) with a torque of $10 \mathrm{kgf}$ [14]-[16] is used as a unit to pull the wire connected to the head of the automatic liquid dispensers bottle. The angle formed between the pulling rope and the head of the bottle $(\theta)$ is $72^{\circ}$. All parts are assembled compactly on a flat datum.

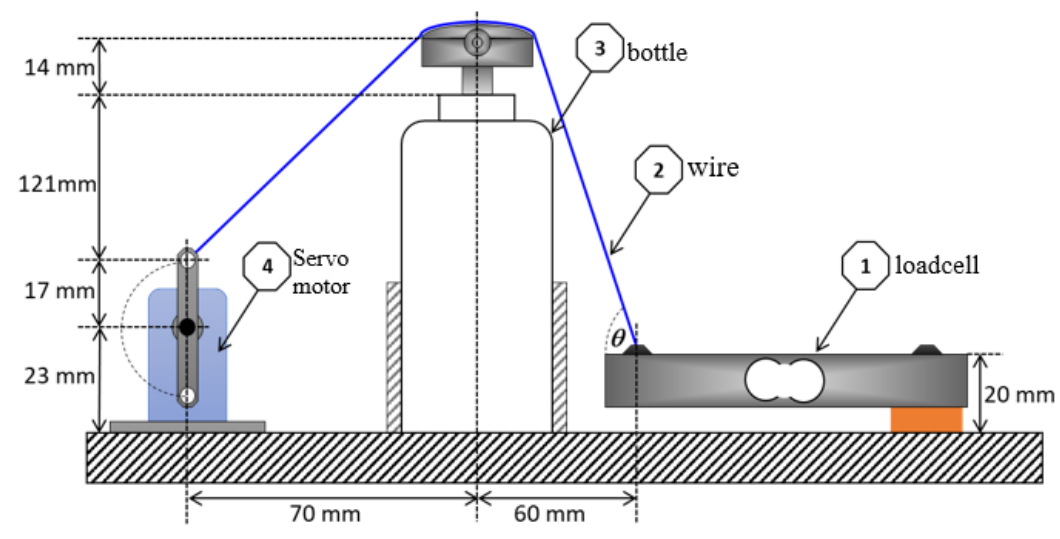

Figure 2. Experimental set-up

A control box for controlling and recording data from sensors was also developed. The control box consists of an ESP826 NodeMCU [17], microcontroller, a push button to activate the servo motor, and a potentiometer to set the servo motor rotation steps. A 4G modulator-demodulator Wi-Fi is used to send data recorded by the microcontroller to the cloud data server online to download it. In full, the experimental flow chart until the data can be obtained is presented in Figure 3. The GUI of the data page is at "http://ttgotomasi.id/logAHSAD/GUI_loggerAHSAD.php".

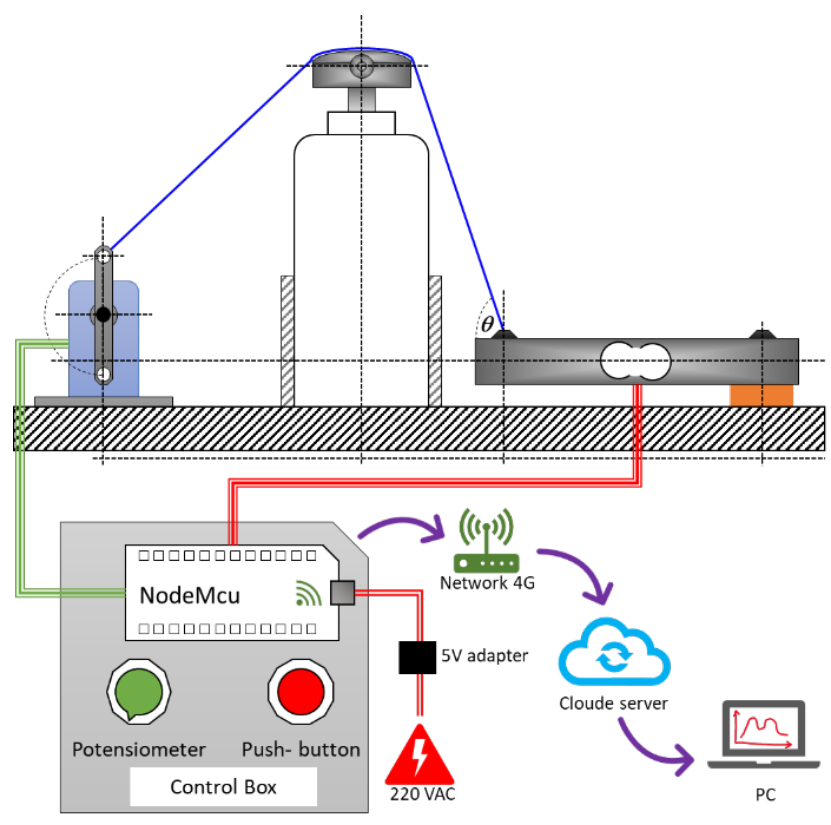

Figure 3. Data logger procedure until it can be accessed by the user 
This study's experimental design was a 3 factorial, completely randomized design with triplicate to compare the differences between the treatment levels. This experiment's treatment consists of the type of fluid, the volume of the fluid, and the rotation step of the servo motor. Three types of fluids used in this study are water, liquid soap, and hand sanitizer gel. The type of fluid for liquid soap and hand sanitizer was chosen because it is a type of liquid commonly used in liquid dispensers. Besides, distilled water is used as a reference for comparison. Three types of treatment levels were used, namely $50 \mathrm{ml}, 150 \mathrm{ml}$, and $250 \mathrm{ml}$. The volume level of the bottles is determined by the minimum and maximum volume of the bottle types chosen.

There are six servo motor rotation steps, namely $180^{\circ}, 150^{\circ}, 120^{\circ}, 90^{\circ}, 60^{\circ}$, and $30^{\circ}$. Each treatment combination was measured 10 times to obtain data on the working push and pull forces. Duncan's different reach test (DMRT) was picked as a technique for making various examinations with a critical distinction at 5\% [18]-[20]. The ANOVA and DMRT were finished by utilizing Microsoft office Excel.

\section{RESULTS AND DISCUSSION}

\subsection{Design of the experimental apparatus}

A push and pull force measurement apparatus for automatic liquid dispensers is presented in Figure 4. The apparatus is designed to use $100 \%$ local electronic components in Indonesia. In general, the cost of the apparatus is not greater than $\$ 68$. This apparatus works: i) Connecting the control box with the server cloud with the help of a $4 \mathrm{G}$ Wi-Fi modulator-demodulator network; ii) Furthermore, the dispenser bottle is filled with a certain volume of liquid to be tested; iii) The drawn line through the head of the dispenser bottle is connected to the servo motor; iv) The servo motor rotation step is set according to the test to be carried out with the control box's potentiometer button; v) Push the push-button button to signal the servo motor so that the push and pull force data is recorded by the load cell sensor. The microcontroller will collect the recorded data, which will then be sent to the cloud server via the $4 \mathrm{G}$ network.

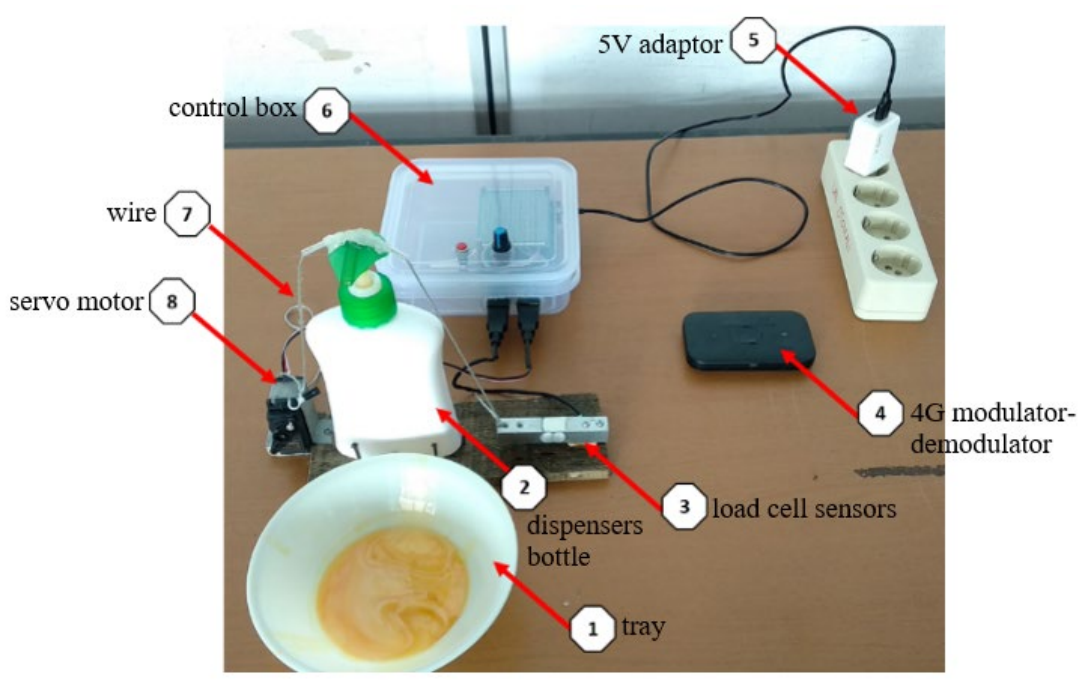

Figure 4. Parts of an experimental apparatus for measuring push and pull forces

\subsection{Push and pull forces spectra}

In general, the characteristics of the push and pull forces spectra are presented in Figure 5. These characteristics of push and pull forces are in line with the characteristics found by Inui and Katsura [21] in the development of force control and timing in a finger-tapping sequence with an attenuated-force tap. The six lines show the force's trajectory generated when automatic liquid dispensers work, from pull force to push force. The push and pull force spectra can be divided into two main regions: the pull force region and the push force region. In the servo motors' rotation steps $30^{\circ}, 60^{\circ}$, and $90^{\circ}$ (for all types of fluids and tested fluid volumes), the automatic liquid dispensers have not reached the maximum pressure step, so that the magnitude of the pull force and push force is relatively the same.

The maximum forces required to release water, liquid soap, and hand sanitizer gel were $19.52 \pm 0.41 \mathrm{~N}, 19.60 \pm 0.45 \mathrm{~N}$, and $19.80 \pm 0.36 \mathrm{~N}$, respectively. The maximum forces required to discharge the

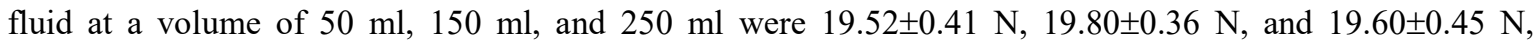


respectively. The maximum force required to discharge the fluid at the rotation step of the servo motor $\left(180^{\circ}\right.$, $150^{\circ}, 120^{\circ}, 90^{\circ}, 60^{\circ}$, and $30^{\circ}$ ) were $19.62 \pm 0.18 \mathrm{~N}, 19.80 \pm 0.36 \mathrm{~N}, 19.45 \pm 0.38 \mathrm{~N}, 19.64 \pm 0.46 \mathrm{~N}, 11.14 \pm 0.37$ $\mathrm{N}$, and $4.95 \pm 0.23 \mathrm{~N}$, respectively.

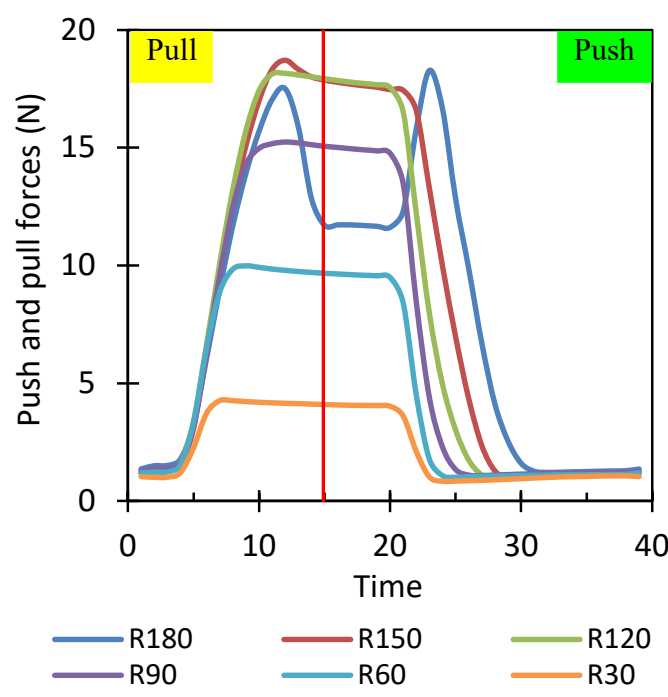

(a)

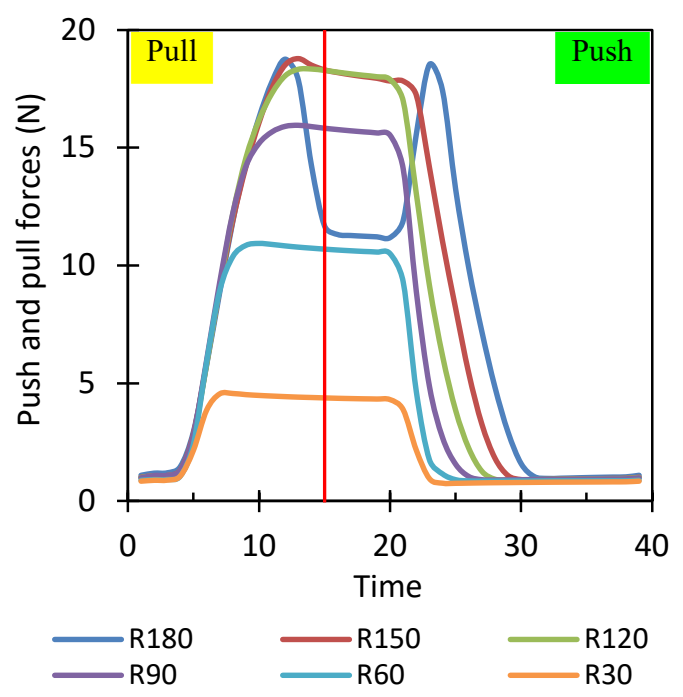

(b)

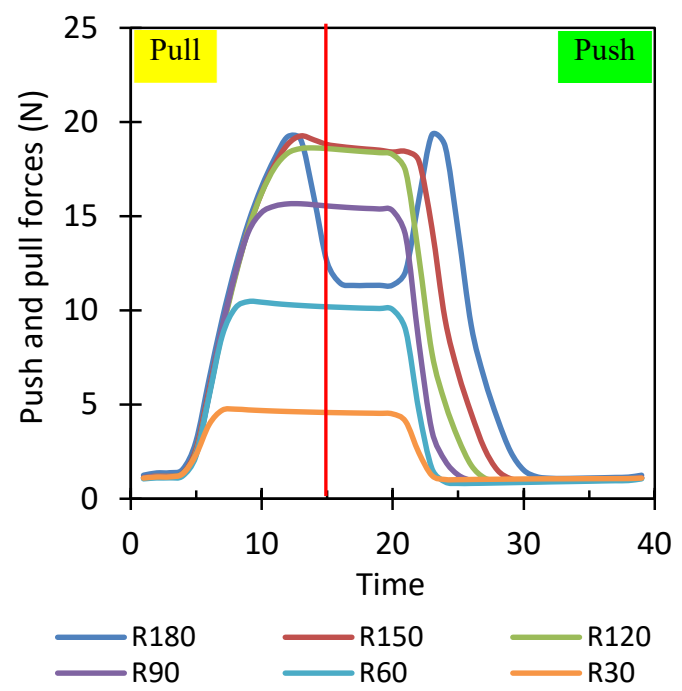

(c)

Figure 5. The characteristics of the push and pull forces of the three fluids tested; (a) hand sanitizer, (b) water, (c) liquid soap

The magnitude of the pull and push force may occur between the servo motor's rotation steps $120^{\circ}$ and $150^{\circ}$. This is evidenced by the rotation step of $180^{\circ}$; there has been a decrease in forces, which is still in the pull forces area. This phenomenon occurs due to the maximum steps achieved by the automatic liquid dispensers' head so that the force generated will decrease. After crossing this limit, the force in the push forces will increase again. The push force will decrease again after passing the maximum step of pressing the automatic liquid dispensers' head.

This study also shows that the rotation step of the servo motor does not always have to be in maximum condition $\left(180^{\circ}\right)$. Optimization of the mechanism is important to get the most appropriate servo motor rotation step. Based on the mechanism of the apparatus being tested, it can be seen that a $120^{\circ}$ or $150^{\circ}$ servo motor rotation step can be applied. Even the $120^{\circ}$ servo motor rotation provides better push and pulls forces than the $150^{\circ}$ servo motor rotation step. This is evidenced by the absence of overshot forces when 
reaching the maximum limit in the pull force area. According to Flanagan and Beltzner [22], this should be avoided to minimize the power's load to be used.

\subsection{Statistical characteristics push and pull forces}

The analysis of variance for push and pull forces is shown in Table 1 . In that analysis, it was determined that the effect of fluid type, fluid volume, and servo motor rotation step were significant at $1 \%$ probability level on the maximum push and pull forces. The interaction effect of fluid type and fluid volume was also significant at $1 \%$ probability level on the maximum push and pull forces. Besides, the Interaction effect of fluid type and servo motor rotation step was significant at $1 \%$ probability level on the maximum push and pull forces. Furthermore, the Interaction effect of fluid volume and servo motor rotation step was significant at $1 \%$ probability level on the maximum push and pull forces. Finally, the Interaction effect of fluid type, fluid volume, and servo motor rotation step was significant at $1 \%$ probability level on the maximum push and pull forces.

Table 1. Analysis of variance of fluid type, fluid volume, servo motor rotation step, and their interactions on the maximum push and pull forces

\begin{tabular}{ccc}
\hline Source of variations & DF & Mean Square push and pull forces \\
\hline Fluid type & 2 & $67677.95^{* *}$ \\
Fluid volume & 2 & $581.43^{* *}$ \\
Servo motor rotation step & 5 & $13799.82^{* *}$ \\
Fluid type $\times$ Fluid volume & 4 & $19505.98^{* *}$ \\
Fluid type $\times$ Servo motor rotation step & 10 & $2334.19^{* *}$ \\
Fluid volume $\times$ Servo motor rotation step & 10 & $617.01^{* *}$ \\
Fluid type $\times$ Fluid volume $\times$ Servo motor rotation step & 20 & $1648.25^{* *}$ \\
Error & 1785 & $38.52^{* *}$ \\
\hline$* *=P \leq 0.01 ; D F:$ degrees of freedom & &
\end{tabular}

According to Table 2, the means comparison of the maximum push and pull forces for three fluid types, three fluid volume, and six servo motor rotation steps did show significant differences. The highest mean push and pull forces were $19.79 \mathrm{~N}$ in hand sanitizer on fluid volume $150 \mathrm{ml}$ at servo motor rotation step $90^{\circ}$, and its lowest value was $4.54 \mathrm{~N}$ in liquid soap on fluid volume $50 \mathrm{ml}$ at servo motor rotation step $30^{\circ}$.

Table 2. Mean comparison of the effects of fluid type, fluid volume, servo motor rotation step, and their interactions on the maximum push and pull forces

\begin{tabular}{|c|c|c|c|c|c|c|c|}
\hline \multirow{3}{*}{ Fluid type } & \multirow{3}{*}{ Fluid volume } & \multicolumn{6}{|c|}{ Mean push and pull forces $(\mathrm{N})$} \\
\hline & & \multicolumn{6}{|c|}{ Servo motor rotation step } \\
\hline & & $30^{\circ}$ & $60^{\circ}$ & $90^{\circ}$ & $120^{\circ}$ & $150^{\circ}$ & $180^{\circ}$ \\
\hline \multirow[t]{6}{*}{ Water } & $50 \mathrm{ml}$ & $4.95 \pm$ & $11.14 \pm$ & $16.63 \pm$ & $19.45 \pm$ & $19.52 \pm$ & $19.3 \pm$ \\
\hline & & $0.22 \mathrm{aku}$ & $0.37 \mathrm{akv}$ & $0.46 \mathrm{akw}$ & $0.38 \mathrm{akx}$ & 0.41 aky & $0.35 \mathrm{akz}$ \\
\hline & $150 \mathrm{ml}$ & $4.82 \pm$ & $10.6 \pm$ & $15.93 \pm$ & $18.38 \pm$ & $19.09 \pm$ & $18.89 \pm$ \\
\hline & & 0.15 alu & 0.16 alv & $0.25 \mathrm{alw}$ & 0.29 alx & 0.26 aly & $0.26 \mathrm{alz}$ \\
\hline & $250 \mathrm{ml}$ & $4.81 \pm$ & $10.93 \pm$ & $15.96 \pm$ & $18.34 \pm$ & $18.79 \pm$ & $18.78 \pm$ \\
\hline & & 0.24 alu & 0.23 alv & 0.32 alw & 0.3 alx & 0.3 aly & $0.3 \mathrm{alz}$ \\
\hline \multirow[t]{6}{*}{ Liquid soap } & $50 \mathrm{ml}$ & $4.54 \pm$ & $9.40 \pm$ & $14.18 \pm$ & $17.33 \pm$ & $17.85 \pm$ & $18.07 \pm$ \\
\hline & & $0.18 \mathrm{bku}$ & $0.22 \mathrm{bkv}$ & $0.23 \mathrm{bkw}$ & $0.18 \mathrm{bkx}$ & 0.45 bky & $0.26 \mathrm{bkz}$ \\
\hline & $150 \mathrm{ml}$ & $4.62 \pm$ & $10.11 \pm$ & $15.53 \pm$ & $18.29 \pm$ & $18.9 \pm$ & $19.16 \pm$ \\
\hline & & $0.12 \mathrm{blu}$ & $0.2 \mathrm{blv}$ & $0.16 \mathrm{blw}$ & $0.11 \mathrm{blx}$ & 0.23 bly & $0.2 \mathrm{blz}$ \\
\hline & $250 \mathrm{ml}$ & $4.76 \pm$ & $10.47 \pm$ & $15.66 \pm$ & $18.62 \pm$ & $19.26 \pm$ & $19.59 \pm$ \\
\hline & & $0.11 \mathrm{blu}$ & $0.17 \mathrm{blv}$ & $0.24 \mathrm{blw}$ & $0.22 \mathrm{blx}$ & 0.32 bly & $0.44 \mathrm{blz}$ \\
\hline \multirow[t]{6}{*}{ Hand sanitizer } & $50 \mathrm{ml}$ & $4.69 \pm$ & $10.24 \pm$ & $15.64 \pm$ & $18.26 \pm$ & $19.03 \pm$ & $18.59 \pm$ \\
\hline & & $0.06 \mathrm{cku}$ & $0.12 \mathrm{ckv}$ & $0.37 \mathrm{ckw}$ & $0.23 \mathrm{ckx}$ & $0.41 \mathrm{cky}$ & $0.16 \mathrm{ckz}$ \\
\hline & $150 \mathrm{ml}$ & $4.61 \pm$ & $10.4 \pm$ & $15.33 \pm$ & $18.08 \pm$ & $19.79 \pm$ & $19.62 \pm$ \\
\hline & & $0.17 \mathrm{clu}$ & $0.18 \mathrm{clv}$ & $0.30 \mathrm{clw}$ & $0.24 \mathrm{clx}$ & 0.35 cly & $0.17 \mathrm{clz}$ \\
\hline & $250 \mathrm{ml}$ & $4.71 \pm$ & $10.14 \pm$ & $15.24 \pm$ & $18.18 \pm$ & $18.72 \pm$ & $18.27 \pm$ \\
\hline & & $0.20 \mathrm{clu}$ & $0.15 \mathrm{clv}$ & $0.25 \mathrm{clw}$ & $0.22 \mathrm{clx}$ & $0.39 \mathrm{cly}$ & $0.29 \mathrm{clz}$ \\
\hline
\end{tabular}

The statistical test results above indicate that treating the type of fluid, the volume of fluid in the dispenser bottle, and the servo motor's rotation step greatly influences the push and pull forces generated by automatic liquid dispensers. This should be an important concern for researchers or engineers who design 
automatic liquid dispensers to estimate the power requirements due to the resulting push and pull forces, especially when using batteries. The power requirement will be closely related to the planned battery capacity.

On the other hand, the push and pull forces influenced by volume indicate that a load cell type sensor can be used to estimate the volume inside the dispenser bottle for liquid soap type. This is based on the push-pull force trend for liquid soap types, which tend to increase with increasing volume in the dispenser bottle. This is important to design the optimum capacity of automatic liquid dispenser bottles. This parameter can also be used to indicate the status of the volume of liquid present in the dispenser bottle through the resulting push and pull forces. This becomes important in the effort to schedule refilling dispensers so that there is no void of fluid. Its application has also been tested by Durrence et al. [23] for the yield monitor for peanut in a basket at combine harvester, Mohanasundaram et al. [24] who designed and implementation of load cell for fuel level measurement, and Siregar et al. [25] which uses loadcell sensors to monitor garbage load capacity in the trash bin.

\section{CONCLUSION}

The magnitude of the push and pull forces acting of automatic liquid dispensers have been measured and analyzed under various treatments. The maximum force required to release the water, liquid soap, and hand sanitizer gel were $19.52 \pm 0.41 \mathrm{~N}, 19.60 \pm 0.45 \mathrm{~N}$, and $19.80 \pm 0.36 \mathrm{~N}$, respectively. The maximum force required to release the fluid at a volume of $50 \mathrm{ml}, 150 \mathrm{ml}$, and $250 \mathrm{ml}$ were amounting to $19.52 \pm 0.41 \mathrm{~N}$, $19.80 \pm 0.36 \mathrm{~N}$, and $19.60 \pm 0.45 \mathrm{~N}$, respectively. The maximum force required to discharge the fluid in the servo motors' rotation steps $180^{\circ}, 150^{\circ}, 120^{\circ}, 90^{\circ}, 60^{\circ}$, and $30^{\circ}$ were $19.62 \pm 0.18 \mathrm{~N}, 19.80 \pm 0.36 \mathrm{~N}$, $19.45 \pm 0.38 \mathrm{~N}, 19.64 \pm 0.46 \mathrm{~N}, 11.14 \pm 0.37 \mathrm{~N}$, dan $4.95 \pm 0.23 \mathrm{~N}$, respectively.

It can also be seen that the treatment of the type of fluid with the volume of fluid has a very significant effect on the maximum push and pull forces. The treatment of the type of fluid by the rotation of the servo motor also has a very significant effect on the maximum push and pull forces. Besides that, the treatment of fluid volume by the rotation of the servo motor has a very significant effect on the maximum push and pull forces. Finally, the three treatments tested (fluid type, fluid volume, and servo motor rotation step) had a very significant effect on the maximum push and pull forces. Last but not least, it is hoped that this can be a reference for researchers and engineers in determining the amount of power required by knowing the magnitude of the force that we have described in this paper. In that respect, under and overdesign risks can be avoided in the design and manufacturing process.

\section{REFERENCES}

[1] M. D. Rahman and I. Anshori, "Libur Sekolah, Siswa SMP Muhammadiyah 8 Batu Ciptakan Dispenser Hand Sanitizer," (in English): "School Holidays, Muhammadiyah 8 Batu Junior High School Students Create Hand Sanitizer Dispenser," Times Indonesia, 2020, accessed October 30, 2020. [Online]. Available: https://www.timesindonesia.co.id/read/news/257347/libur-sekolah-siswa-smp-muhammadiyah-8-batu-ciptakandispenser-hand-sanitizer

[2] Anonymous, "Students of the Faculty of Engineering, Unkhair Donate Automatic Handwashing Places to the Hospital," (in Indonesian Language): 2021, accessed October 31, 2020. [Online]. Available: https://unkhair.ac.id/mahasiswa-fakultas-teknik-unkhair-sumbang-tempat-cuci-tangan-otomatis-ke-rsud/.

[3] A. Karn, R. Kanchi, and S. S. Deo, "Design and Development of an Automated Monitored Hand Hygiene System to Curb Infection Spread in Institutional Settings during COVID-19 Pandemic," Proceedings of International Conference on Advances in the Field of Health, Safety, Fire, Environment \& Allied Sciences (HSFEA 2020), 2020.

[4] A. Edgar-Tanzil, "Designing for a Pandemic: A Hands-Free Soap Dispenser," WWU Honors Program Senior Projects, 2020.

[5] S. Bánsághi, H. Soule, C. Guitart, D. Pittet, and T. Haidegger, "Critical reliability issues of common type alcoholbased handrub dispensers," Antimicrobial Resistance and Infection Control, vol. 9, pp. 1-13, 2020.

[6] Á. Lehotsky et al., "Hand hygiene technique assessment using electronic equipment in 26 Hungarian healthcare institutions," Orvosi hetilap, vol. 158, no. 29, pp. 1143-1148, 2017.

[7] P. Han, "Additive design and manufacturing of jet engine parts," Engineering, vol. 3, no. 5, pp. 648-652, 2017.

[8] A. Sitorus, N. Novrinaldi, and R. Bulan, "Non-invasive moisture content measurement system based on the ESP8266 microcontroller," Bulletin of Electrical Engineering and Informatics (BEEI), vol. 9, no. 3, pp. 924-932, 2020, doi: 10.11591/eei.v9i3.2178.

[9] J. Zhu and A. Deshmukh, "Application of Bayesian decision networks to life cycle engineering in Green design and manufacturing," Engineering Applications of Artificial Intelligence, vol. 16, no. 2, pp. 91-103, 2003, doi: 10.1016/S0952-1976(03)00057-5.

[10] C. W. Babbitt, S. Althaf, F. C. Rios, M. M. Bilec, and T. Graedel, "The role of design in circular economy solutions for critical materials," One Earth, vol. 4, no. 3, pp. 353-362, 2021, doi: 10.1016/j.oneear.2021.02.014. 
[11] T. Jaysrichai, "Load cells application for developing weight-bearing detection via wireless connection," Open Biomedical Engineering Journal, vol. 12, no. 1, pp. 101-107, 2018, doi: 10.2174/1874120701812010101.

[12] R. Rathore, A. K. Singh, and H. Choudhary, "Design, development, and calibration of bipedal force-plate for post prosthesis gait rehabilitation," Materials Today: Proceedings, vol. 44, pp. 4873-4877, 2021, doi: 10.1016/j.matpr.2020.11.706

[13] A. Hastawan et al., "Comparison of testing load cell sensor data sampling method based on the variation of time delay," in IOP Conference Series: Earth and Environmental Science, vol. 700, 2021, Art. No. 012018.

[14] J. L. Manríquez-Legarda et al., "Temperature control for rotomolding machine," 18th LACCEI International MultiConference for Engineering, Education, and Technology: "Engineering, Integration, and Alliances for a Sustainable Development" "Hemispheric Cooperation for Competitiveness and Prosperity on a Knowledge-Based Economy”, Buenos Aires, Argentina, 29-31 July 2020, pp. 1-6.

[15] V. H. Benitez, R. Symonds, and D. E. Elguezabal, "Design of an affordable IoT open-source robot arm for online teaching of robotics courses during the pandemic contingency," HardwareX, vol. 8, Art. no. e00158, 2020, doi: 10.1016/j.ohx.2020.e00158.

[16] Y. Wu, M. Wang and N. M. Mayer, "A new type of eye-on-hand robotic arm system based on a low-cost recognition system," 2017 International Conference on Advanced Robotics and Intelligent Systems (ARIS), 2017, pp. 110-114, doi: 10.1109/ARIS.2017.8297200.

[18] A. Phuphaphud, K. Saengprachatanarug, J. Posom, K. Maraphum, and E. Taira, "Non-destructive and rapid measurement of sugar content in growing cane stalks for breeding programmes using visible-near infrared spectroscopy," Biosystems Engineering, vol. 197, pp. 76-90, 2020, doi: 10.1016/j.biosystemseng.2020.06.012.

[19] K. W. Li and R. Yu, "Assessment of grip force and subjective hand force exertion under handedness and postural conditions," Applied ergonomics, vol. 42, no. 6, pp. 929-933, 2011, doi: 10.1016/j.apergo.2011.03.001.

[20] X. Zhang and Y. Chen, "Soil disturbance and cutting forces of four different sweeps for mechanical weeding," Soil and Tillage Research, vol. 168, pp. 167-175, 2017, doi: 10.1016/j.still.2017.01.002.

[21] N. Inui and Y. Katsura, "Development of force control and timing in a finger-tapping sequence with an attenuatedforce tap," Motor Control, vol. 6, no. 4, pp. 333-346, 2002, doi: 10.1123/mcj.6.4.333.

[22] J. R. Flanagan and M. A. Beltzner, "Independence of perceptual and sensorimotor predictions in the size-weight illusion," Nature neuroscience, vol. 3, no. 7, pp. 737-741, 2000, doi: 10.1038/76701.

[23] J. Durrence, T. Hamrita, and G. Vellidis, "A load cell based yield monitor for peanut feasibility study," Precision Agriculture, vol. 1, no. 3, pp. 301-317, 1999, doi: 10.1023/A:1009925125359.

[24] S. Mohanasundaram, P. Manikandan, and R. Monisha, "Design and implementation of load cell based fuel level measurement," Int. Conf. on Computer Commu. and Informatics, 2014, pp. 1-6, doi: 10.1109/ICCCI.2014.6921837.

[25] B. Siregar, D. Fadhillah, U. Andayani, H. Pranoto, and F. Fahmi, "Simulation of waste transport monitoring based on garbage load capacity using load cell," in 2017 International Conference on ICT For Smart Society (ICISS), 2017, pp. 1-7, doi: 10.1109/ICTSS.2017.8288883. 